\title{
EVALUASI KINERJA DAN ANALISIS TINGKAT KEPUASAN PENUMPANG DI STASIUN KRL GROGOL
}

\author{
(Performance Evaluation and Analysis of Passengers Satisfaction Levels at KRL Grogol \\ Station)
}

\author{
Jessica Paulina ${ }^{1}$, Christina Sari $^{1}$, Dewi Rintawati ${ }^{1}$ \\ ${ }^{1}$ Program Studi Teknik Sipil Universitas Trisakti \\ E-mail: jessipaul33@gmail.com
}

Diterima 10 September 2020, Disetujui 24 Oktober 2020

\begin{abstract}
ABSTRAK
Stasiun Grogol merupakan Stasiun KRL Commuter Line yang terletak di Jalan Prof. Dr. Latumenten, Jelambar, Jakarta Barat. Stasiun ini tergolong stasiun kelas kecil dan baru diaktifkan pada bulan Juni 2015 , sejak itu peningkatan jumlah penumpang terjadi setiap tahunnya. Stasiun Grogol memiliki potensi untuk lebih dikembangkan, didukung dengan lokasi yang strategis sehingga banyak penumpang yang menggunakan KRL Commuter Line di stasiun ini. Tujuan dari penelitian ini yaitu untuk mengevaluasi kinerja dan menganalisis tingkat kepuasan penumpang. Penelitian ini dilakukan dengan observasi secara langsung untuk mengevaluasi kinerja pelayanan dan fasilitas yang dibandingkan dengan Standar Pelayanan Minimum pada PM 63 Tahun 2019. Kuesioner juga dibagikan untuk menganalisis tingkat kepuasan penumpang terhadap pelayanan dan fasilitas yang diberikan. Hasil dari kuesioner akan melalui uji validitas dan uji reliabilitas, kemudian diolah menggunakan metode Importance Performance Analysis (IPA). Berdasarkan hasil evaluasi, Stasiun Grogol telah memenuhi 78,72\% tolok ukur yang terdapat pada PM 63 Tahun 2019. Dari tingkat kepuasan penumpang, nilai rata-rata tingkat kesesuaian masih di bawah 100\%, yaitu 77,07\%. Berdasarkan hasil tersebut, kinerja pelayanan dan fasilitas di Stasiun Grogol masih belum sesuai dengan yang diharapkan dan belum memenuhi kepuasan penumpang. Hal ini dapat dilihat dari posisi atribut yang masih berada di kuadran A yang menjadi prioritas utama untuk diperbaiki kinerjanya.
\end{abstract}

Kata Kunci: Kinerja Stasiun, Tingkat Kepuasan Penumpang, Importance Performance Analysis (IPA).

\begin{abstract}
Grogol Station is a Commuter Line KRL Station located on Prof. Dr. Latumenten Street, Jelambar, West Jakarta. This station is classified as a small class station and activated in June 2015, the number of passengers increase annually since. Grogol Station has the potential to be further developed, supported by a strategic location so that many passengers used the KRL Commuter Line in this station. The purpose of this study is to evaluate the performance and to analyze the level of passenger satisfaction. This study used direct observation to evaluate the performance of services and facilities which compared with the Minimum Services Standards at PM 63 in 2019. Questionnaires were also distributed to analyze the level of passenger satisfaction with the services and facilities provided. The results of the questionnaire went through validity and reliability tests, then processed using the Importance Performance Analysis (IPA) method. Based on the results of the evaluation, Grogol Station has fulfilled $78,72 \%$ of the benchmarks in PM 63 of 2019. From the level of passenger satisfaction, the average value of conformity is still below $100 \%$, that is $77,07 \%$. According to the result, the performance of services and facilities at Grogol Station is still not as expected and does not satisfy the passenger yet. It is seen from the position of attributes that are still in quadrant $A$ which is the main priority to be rectified their performance.
\end{abstract}

Keywords: Performance of Station, Passenger Satisfaction Levels, Importance Performance Analysis (IPA). 


\section{PENDAHULUAN}

Kota yang maju dan berkembang akan memberikan daya tarik tersendiri bagi masyarakat dan membuat pergerakan masyarakatnya pun semakin tinggi. Seperti halnya terjadi di Ibu Kota Negara Indonesia, yaitu DKI Jakarta dengan segala kelengkapan fasilitas yang dimiliki menjadikan kota ini sebagai pusat berbagai kegiatan. Hal ini tentu memberikan kesempatan bagi para kaum komuter melakukan kegiatannya ke pusat kota. Pergerakan rutin para kaum komuter tersebut tentu menambah jumlah mobilitas dan pergerakan penduduk yang keluarmasuk Jakarta. Kondisi ini harus didukung dengan penggunaan moda transportasi umum yang mampu memenuhi kebutuhan mobilitas tersebut, salah satunya KRL Commuter Line. Moda transportasi massal ini menjadi salah satu moda yang diandalkan masyarakat untuk memenuhi kebutuhan perjalanannya.

Semakin berkembangnya kebutuhan dan aktivitas yang beragam tentu memberi tuntutan terhadap ketersediaan sarana dan prasarana yang baik, salah satunya kebutuhan akan tempat pemberhentian sementara untuk suatu moda transportasi. Seperti halnya stasiun yang menjadi media bagi manusia ataupun barang dalam melakukan perpindahannya dan berfungsi untuk memulai dan mengakhiri suatu perjalanan (Pradana et al., 2018).

Meningkatnya kebutuhan perjalanan masyarakat, terlebih yang menggunakan KRL Commuter Line juga terjadi di Stasiun Grogol yang terletak di Jalan Prof. Dr. Latumenten, Jelambar, Jakarta Barat. Stasiun ini merupakan stasiun kelas III (kecil) yang baru diaktifkan pada bulan Juni 2015, namun peningkatan jumlah penumpang terjadi setiap tahunnya, seperti yang dapat dilihat pada Tabel 1.

Tabel 1. Jumlah Penumpang di Stasiun Grogol Tahun 2015-2019

\begin{tabular}{cc}
\hline Tahun & Jumlah Penumpang \\
\hline 2015 & 472.317 \\
2016 & 1.547 .650 \\
2017 & 1.789 .158 \\
2018 & 1.961 .987 \\
2019 & 2.114 .089 \\
\hline
\end{tabular}

Sumber: (PT. KCl, 2020)

Dari data tersebut menandakan bahwa Stasiun Grogol memiliki potensi untuk lebih dikembangkan, didukung dengan lokasi stasiun yang strategis juga menjadi salah satu faktor banyaknya penumpang yang menggunakan KRL Commuter Line di stasiun ini. Seiring dengan semakin banyaknya penumpang di Stasiun Grogol, tentu harus diikuti dengan memaksimalkan kinerja stasiun untuk meningkatkan kepuasan para penumpang

Penelitian ini bertujuan untuk mengevaluasi kinerja pelayanan dan fasilitas di Stasiun Grogol yang akan dibandingkan dengan Standar Pelayanan Minimum pada PM 63 Tahun 2019 dan menganalisis tingkat kepuasan penumpang terhadap pelayanan dan fasilitas yang telah diberikan melalui penyebaran kuesioner yang akan diolah dengan menggunakan metode Importance Performance Analysis (IPA).

\section{METODE}

Tahapan penelitian ini dimulai dengan melakukan observasi untuk mengevaluasi kinerja pelayanan dan fasilitas di Stasiun Grogol saat ini berdasarkan Peraturan Menteri Perhubungan Republik Indonesia Nomor PM 63 Tahun 2019 tentang Standar Pelayanan Minimum Angkutan Orang dengan Kereta Api di Stasiun untuk Pelayanan Kereta Rel Listrik, Light Rail Transit, Mass Rapid Transit, dan Kereta Api Bandara yang mencakup 6 aspek pelayanan yaitu keselamatan, keamanan, kehandalan/keteraturan, kenyamanan, kemudahan, dan kesetaraan.

Standar Pelayanan Minimum merupakan ukuran minimum pelayanan yang harus dipenuhi oleh penyedia layanan yang dilengkapi tolok ukur sebagai pedoman penyelenggaraan pelayanan dan acuan penilaian kualitas pelayanan sehingga menghasilkan pelayanan yang berkualitas, cepat, mudah, terjangkau dan terukur (Peraturan Menteri Perhubungan Republik Indonesia Nomor PM 63 Tahun 2019 Tentang Standar Pelayanan Minimum Angkutan Orang Dengan Kereta Api).

Selanjutnya untuk menganalisis tingkat kepuasan penumpang yaitu dengan memberikan kuesioner yang juga berkaitan dengan Standar Pelayanan Minimum pada PM 63 Tahun 2019. Kuesioner terdiri dari masingmasing 25 pertanyaan untuk tingkat kinerja dan tingkat kepentingan yang diberikan secara online melalui google form kepada pengguna jasa atau penumpang KRL Commuter Line di Stasiun Grogol yang tidak diketahui secara pasti jumlahnya, oleh karena itu dalam menentukan jumlah sampel menggunakan Rumus Wibisono yang terdapat pada Riduwan \& Akdon (2015):

$\mathrm{n}=\left(\frac{\mathrm{Z}_{\alpha / 2} \mathrm{x} \sigma}{\mathrm{e}}\right)^{2}$

dimana:

$\mathrm{Z}_{\alpha / 2}=$ nilai $\mathrm{z}$ yang diperoleh dari tabel normal (tingkat kepercayaan 95\% $=1,96$ )

$\sigma \quad=$ standar deviasi (digunakan 25\% $=0,25$ ) 

e $=$ toleransi tingkat kesalahan dalam pengambilan
sampel (digunakan 5\% = 0,05)
$\mathrm{n} \quad$ = jumlah sampel yang diperoleh

Berdasarkan rumus tersebut diperoleh jumlah sampel sebanyak 96,04 sampel yang dibulatkan menjadi 100 sampel.

Teknik pengambilan sampel yang digunakan adalah non-probability sampling yaitu purposive sampling. Non-probability sampling merupakan pengambilan sampel tanpa memberikan kesempatan atau peluang yang sama untuk setiap anggota populasi yang diambil sebagai sampel. Purposive sampling merupakan pengambilan sampel yang didasarkan dengan pertimbangan atau kriteria tertentu (Sugiyono, 2017). Melalui teknik tersebut setiap sampel yang terpilih merupakan sampel yang sesuai dengan kriteria yang telah ditentukan, yaitu orang-orang yang pernah menggunakan KRL Commuter Line di Stasiun Grogol minimal 3 kali dalam kurun waktu satu tahun terakhir, sehingga dapat mengetahui kualitas pelayanan di Stasiun Grogol.

Hasil dari kuesioner akan melalui uji validitas dan uji reliabilitas menggunakan software SPSS versi 23. Uji validitas yaitu alat ukur yang akan menunjukkan valid atau tidaknya suatu instrumen atau atribut pada kuesioner (Saptutyningsih \& Setyaningrum, 2020). Pengujian validitas data dilakukan menggunakan Uji Korelasi Pearson Product Moment. Instrumen dikatakan valid jika $r_{\text {hitung }}>$ $r_{\text {tabel }}$, namun jika $r_{\text {hitung }}<r_{\text {tabel }}$ maka instrumen tidak valid dan tidak dapat digunakan. Pada penelitian ini, jumlah responden yang digunakan yaitu 100 responden dengan taraf signifikansi 5\%, maka diperoleh $r_{\text {tabel }}=0,195$. Instrumen yang valid akan melalui uji reliabilitas untuk mengetahui konsistensi suatu instrumen atau atribut pada kuesioner. Reliabilitas merupakan kestabilan hasil pengukuran secara repetitif dari masa ke masa. Syarat sebuah instrumen reliabel adalah jika Cronbach's Alpha $>0,7$ dengan skala pengukuran pada Tabel 2 (Saptutyningsih \& Setyaningrum, 2020).

Tabel 2. Kriteria Reliabilitas

\begin{tabular}{c|c}
\hline Cronbach's Alpha & Arti \\
\hline$>0,9$ & Reliabilitas Sempurna \\
$0,70-0,90$ & Reliabilitas Tinggi \\
$0,50-0,70$ & Reliabilitas Moderat \\
$<0,50$ & Reliabilitas Rendah \\
\hline \multicolumn{2}{c}{ Sumber:(Saptutyningsih \& Setyaningrum, 2020) }
\end{tabular}

Instrumen pada kuesioner yang valid dan reliabel akan diolah menggunakan metode Importance Performance Analysis (IPA). Metode ini menggunakan skala likert 5 tingkat seperti pada Tabel 3.
Tabel 3. Skor atau Bobot Penilaian

\begin{tabular}{ccc} 
Skor & $\begin{array}{c}\text { Tingkat } \\
\text { Kepentingan } \\
\text { (Importance) }\end{array}$ & $\begin{array}{c}\text { Tingkat Kinerja } \\
\text { (Performance) }\end{array}$ \\
\hline 5 & Sangat Penting & Sangat Baik \\
4 & $\begin{array}{c}\text { Penting } \\
\text { Baik }\end{array}$ \\
2 & Cukup Penting & Cukup Baik \\
1 & Kurang Penting & Kurang Baik \\
Tidak Penting & Tidak Baik \\
\hline
\end{tabular}

Sumber: (Supranto, 2012)

Metode IPA telah diterima dan digunakan oleh berbagai bidang kajian karena mudah diaplikasikan dan tampilan hasil analisisnya memberi kemudahan untuk usulan perbaikan kinerja (Martinez, 2003). Metode ini diawali dengan analisis tingkat kesesuaian $\left(\mathrm{TK}_{\mathrm{i}}\right)$ yang diperoleh dengan membandingkan skor kinerja (pelaksanaan) dengan skor kepentingan (harapan). Jika nilai $\mathrm{TK}_{\mathrm{i}}>100 \%$, kinerja dianggap sudah memenuhi kepuasan konsumen. Namun jika $\mathrm{TK}_{\mathrm{i}}<100 \%$, maka kinerjanya belum dapat memenuhi kepuasan konsumen. Menurut Sukardi \& Chandrawatisma (2006), jika nilai $\mathrm{TK}_{\mathrm{i}}$ mendekati $100 \%$ dan berada di atas rata-rata, maka dapat dikatakan tingkat kesesuaian sudah baik. Rumus yang digunakan yaitu:

$\mathrm{TK}_{\mathrm{i}}=\frac{\mathrm{X}_{\mathrm{i}}}{\mathrm{Y}_{\mathrm{i}}} \times 100 \%$

dimana:

$\mathrm{TK}_{\mathrm{i}}=$ tingkat kesesuaian responden

$\mathrm{X}_{\mathrm{i}}=$ skor penilaian kinerja

$Y_{i}=$ skor penilaian kepentingan

Setelah itu dilanjutkan dengan melakukan pemetaan atau plot hasil perhitungan ke dalam diagram kartesius. Pada diagram kartesius, sumbu mendatar diisi dengan skor rata-rata penilaian terhadap tingkat kinerja $(X)$ dan sumbu tegak diisi dengan skor rata-rata penilaian terhadap tingkat kepentingan ( $Y$ ). Rumus yang digunakan yaitu:

$\overline{\mathrm{X}}=\frac{\sum \mathrm{X}_{\mathrm{i}}}{\mathrm{n}}$

$\overline{\mathrm{Y}}=\frac{\sum \mathrm{Y}_{\mathrm{i}}}{\mathrm{n}}$

dimana:

$\bar{X}=$ skor rata-rata tingkat kinerja

$\bar{Y}=$ skor rata-rata tingkat kepentingan

$\mathrm{n}$ = jumlah responden

Pada diagram kartesius setiap kuadran dibatasi dengan dua garis yang berpotongan tegak lurus, yaitu $\overline{\overline{\mathrm{X}}}$ dan $\overline{\overline{\mathrm{Y}}}$. Perpotongan dua garis yang tegak lurus tersebut dapat menggunakan rumus berikut: 
$\overline{\bar{X}}=\frac{\sum_{\mathrm{i}=1}^{\mathrm{n}} \overline{\mathrm{X}}_{\mathrm{i}}}{\mathrm{k}}$
$\overline{\bar{Y}}=\frac{\sum_{\mathrm{i}=1}^{\mathrm{n}} \overline{\mathrm{Y}}_{\mathrm{i}}}{\mathrm{k}}$

dimana:

$\overline{\overline{\mathrm{X}}}=$ rata-rata dari rata-rata skor tingkat kinerja

$\overline{\bar{Y}}=$ rata-rata dari rata-rata skor tingkat

kepentingan

$\mathrm{k}$ = banyak atribut/faktor yang berpengaruh terhadap

penilaian kepuasan

Setelah itu dapat dilakukan analisis diagram kartesius dengan cara melihat posisi dari atribut tersebut yang terletak di salah satu dari 4 kuadran pada diagram kartesius, seperti pada Gambar 1 berikut:

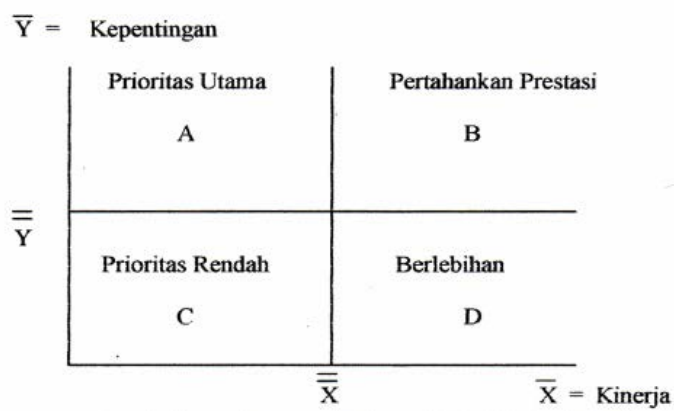

Gambar 1. Diagram Kartesius Metode IPA

Sumber: Supranto (2012)

\section{HASIL DAN PEMBAHASAN}

Evaluasi Kinerja Pelayanan dan Fasilitas di Stasiun Grogol Berdasarkan Standar Pelayanan Minimum Pada PM 63 Tahun 2019

Evaluasi ini dilakukan melalui observasi dengan cara membandingkan kondisi stasiun saat ini dengan Standar Pelayanan Minimum yang terdapat pada PM 63 Tahun 2019. Tolok ukur yang digunakan yaitu tolok ukur untuk stasiun dengan penumpang yang kurang dari 10.000 per harinya. Hasil observasi yang telah dilakukan dapat dilihat pada Tabel 4.

Berdasarkan hasil observasi pada Tabel 4, Stasiun Grogol telah memenuhi 37 dari 47 tolok ukur yang ditinjau. Terdapat 10 tolok ukur yang belum terpenuhi, yaitu :

1. Tabung oksigen;

2. Vending machine untuk pembelian tiket elektronik;

3. Fasilitas wastafel pada toilet pria;

4. Toilet difabel untuk pria;

5. Area toilet yang tidak bersih dan berbau;

6. Informasi angkutan lanjutan;

7. Tempat parkir;

8. Kelancaran sirkulasi kendaraan yang masuk, keluar, dan parkir;

9. Jalur pedestrian yang dilengkapi dengan guiding block
10. Ruangan ibu menyusui.

Dari hasil observasi yang telah dilakukan untuk mengevaluasi kinerja pelayanan dan fasilitas di Stasiun Grogol dapat disimpulkan bahwa Stasiun Grogol telah memenuhi $78,72 \%$ tolok ukur yang ada di Standar Pelayanan Minimum pada PM 63 Tahun 2019.

Analisis Tingkat Kepuasan Penumpang di Stasiun Grogol Terhadap Kinerja Pelayanan dan Fasilitas yang diberikan

\section{Pengujian Validitas dan Reliabilitas Data} Kuesioner

Berdasarkan hasil pengujian validitas data diperoleh 25 atribut pelayanan untuk tingkat kinerja dan tingkat kepentingan memiliki nilai $r_{\text {hitung }}>r_{\text {tabel }}(0,195)$, maka semua atribut tersebut valid. Setelah data kuesioner dinyatakan valid, maka dilanjutkan dengan pengujian reliabilitas. Dari hasil pengujian reliabilitas diperoleh 25 atribut pelayanan pada tingkat kinerja dan tingkat kepentingan yang memiliki nilai Cronbach's Alpha $>0,7$ dan masuk ke dalam kategori reliabilitas sempurna. Hasil pengujian validitas dan reliabilitas data kuesioner dapat dilihat pada Tabel 5 dan Tabel 6 .

\section{Karakteristik Responden}

Karakteristik responden yang mengisi kuesioner dapat dilihat pada Tabel 7 . 
Tabel 4. Hasil Observasi Kinerja Pelayanan dan Fasilitas di Stasiun Grogol Berdasarkan Standar Pelayanan Minimum Pada PM 63 Tahun 2019

\section{No Jenis Pelayanan \\ Tolok Ukur \\ 1

\begin{tabular}{cc}
\multicolumn{2}{c}{ Kondisi di } \\
Stasiun \\
\hline Tersedia & Tidak \\
& Tersedia
\end{tabular} \\ Keselamatan}

Informasi dan fasilitas
keselamatan

\section{Alat pemadam kebakaran}

2 Stiker titik kumpul evakuasi

3 Petunjuk jalur dan prosedur evakuasi

4 Stiker nomor telpon darurat

1 Fasilitas obat-obatan

Informasi dan fasilitas

kesehatan

-

Peron

2 Kursi roda

3 Tandu

4 Tabung oksigen

Celah antara tepi peron dengan badan kereta

maksimal $20 \mathrm{~cm}$

2 Selisih ketinggian lantai peron dengan lantai kereta

$20 \mathrm{~cm}$

Keterangan

Lantai peron terbebas dari kegiatan komersial,

tidak licin, tidak tergenang air, dan dilengkapi:

a. Marka petunjuk/pembatas antrean naik/turun

3 b. Marka/guiding block untuk petunjuk jalan tuna netra

c. Safety line minimal $35 \mathrm{~cm}$ dari tepi peron atau tersedia PSD (Platform Screen Door)

\begin{tabular}{|c|c|c|c|c|c|}
\hline & Kanopi peron stasiun & 1 & $\begin{array}{l}\text { Panjang kanopi peron sesuai dengan panjang } \\
\text { peron }\end{array}$ & $\sqrt{ }$ & $\begin{array}{l}\text { Panjang kanopi peron sesuai dengan panjang } \\
\text { peron }\end{array}$ \\
\hline & Assembly point & 1 & Area titik kumpul yang diberi tanda & $\sqrt{ }$ & $\begin{array}{l}\text { Tersedia area titik kumpul yang berada di depan } \\
\text { pintu timur stasiun }\end{array}$ \\
\hline 2 & \multicolumn{5}{|c|}{ Keamanan } \\
\hline & Fasilitas keamanan & 1 & CCTV & $\sqrt{ }$ & $\begin{array}{l}\text { Tersedia CCTV di setiap area publik yaitu hall dan } \\
\text { sepanjang area peron }\end{array}$ \\
\hline & Petugas keamanan & 1 & Petugas keamanan yang mudah dilihat, minimal 1 & $\sqrt{ }$ & Terdapat 27 petugas keamanan yang telah \\
\hline
\end{tabular}

Tersedia alat pemadam kebakaran ukuran kecil dan ukuran besar

Tersedia stiker titik kumpul evakuasi di depan pintu timur stasiun

Tersedia petunjuk jalur dan prosedur evakuasi yang diletakkan di tempat strategis yaitu di hall dan sepanjang area peron

Tersedia stiker nomor telpon darurat di hall stasiun Tersedia fasilitas obat-obatan di ruang kepala stasiun

Tersedia kursi roda di ruang informasi Tersedia tandu di ruang informasi

Tidak tersedia

Celah tepi peron dengan badan kereta $20 \mathrm{~cm}$

Selisih ketinggian lantai peron dengan lantai kereta $20 \mathrm{~cm}$

Lantai peron terbebas dari kegiatan komersial, tidak licin, tidak tergenang air, sudah dilengkapi dengan pembatas antrean penumpang, guiding block, dan safety line

Terdapat 27 petugas keamanan yang telah 


\begin{tabular}{|c|c|c|c|}
\hline \multirow{2}{*}{ No } & \multirow{2}{*}{ Jenis Pelayanan } & \multirow{2}{*}{ Tolok Ukur } & $\begin{array}{l}\text { Kondisi di } \\
\text { Stasiun }\end{array}$ \\
\hline & & & $\begin{array}{cc}\text { Tersedia } & \text { Tidak } \\
\text { Tersedia }\end{array}$ \\
\hline
\end{tabular}

orang dan ditempatkan sesuai kondisi stasiun

ditempatkan di area publik yaitu hall dan area peron stasiun

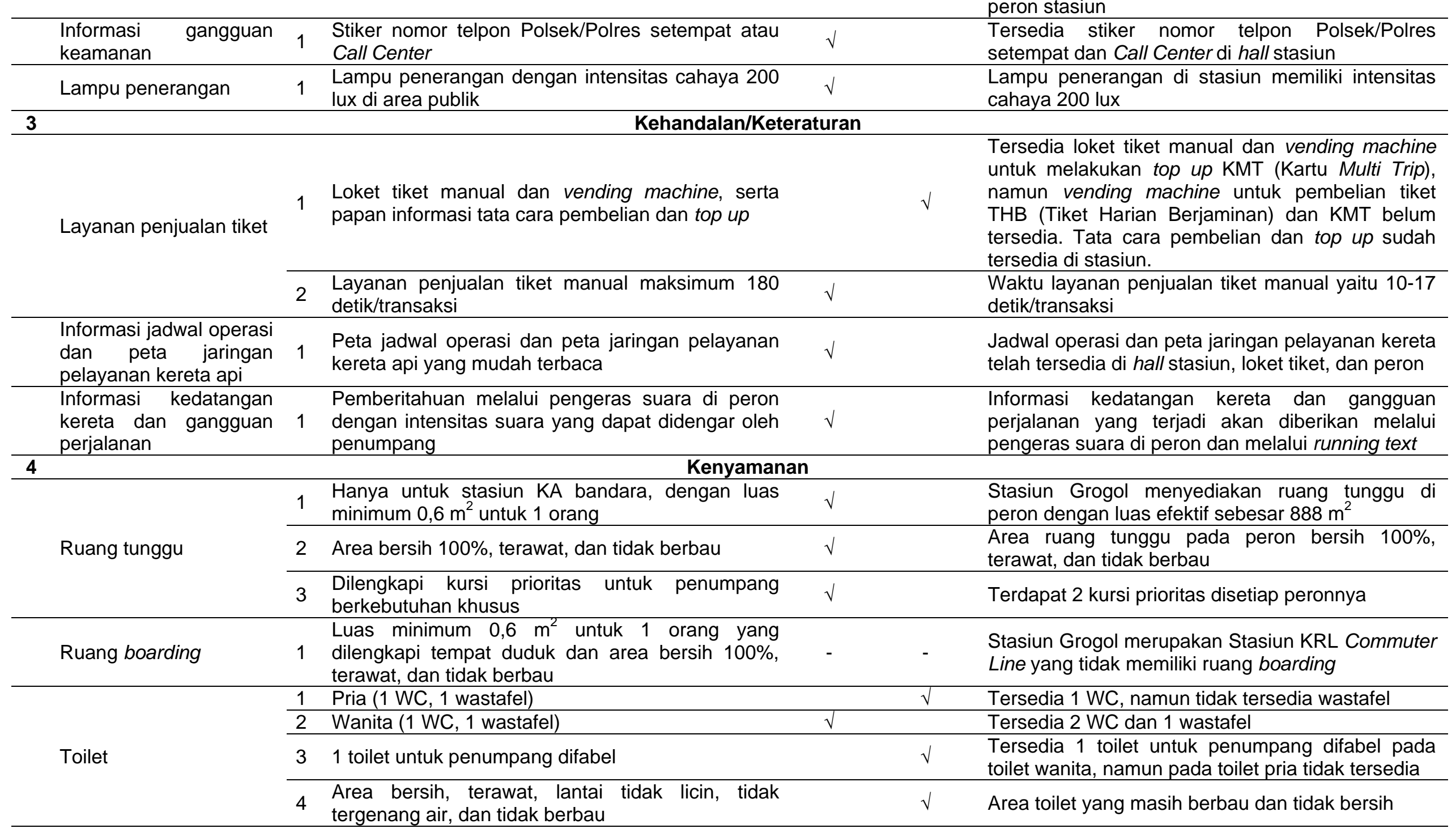




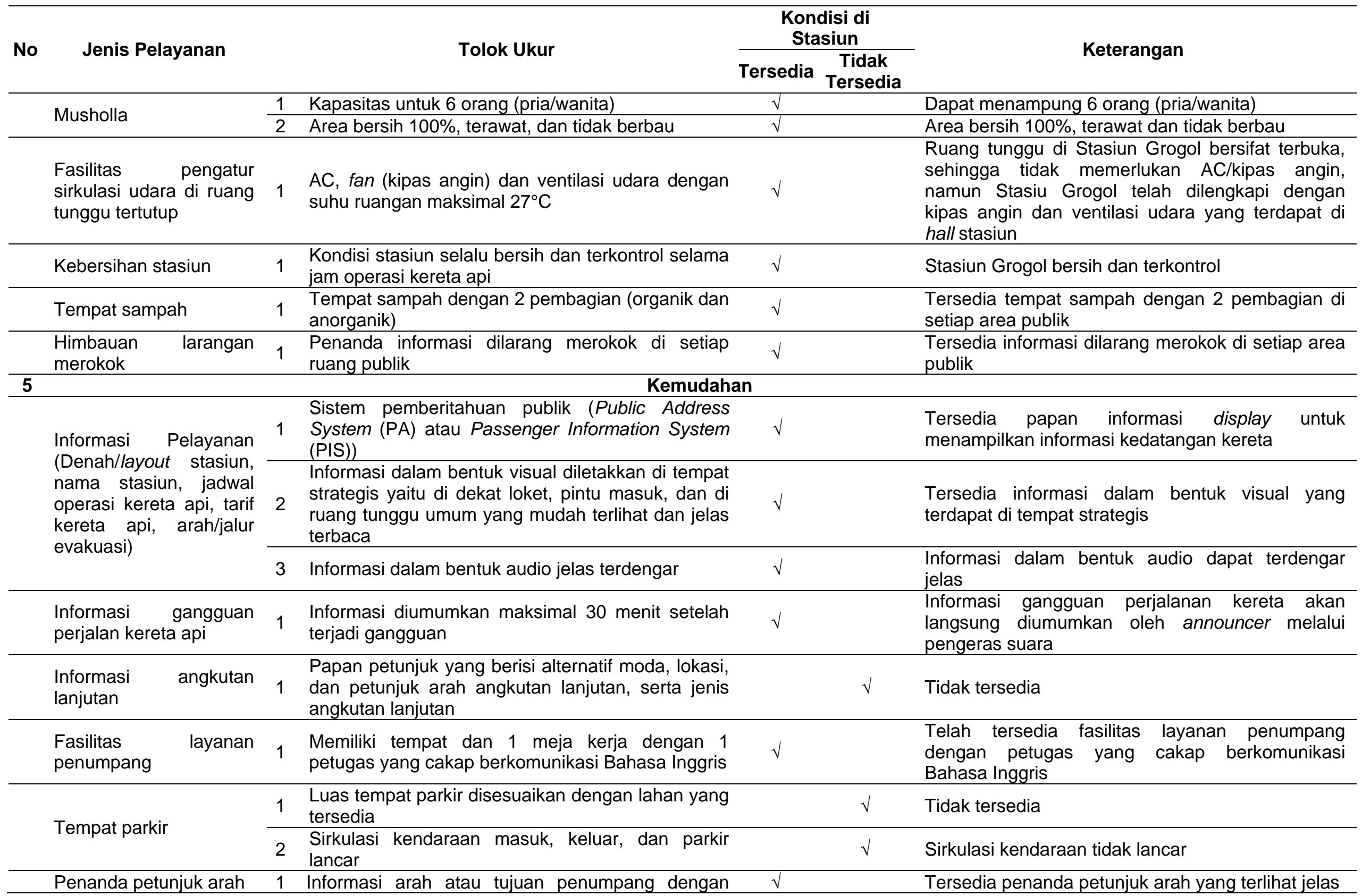




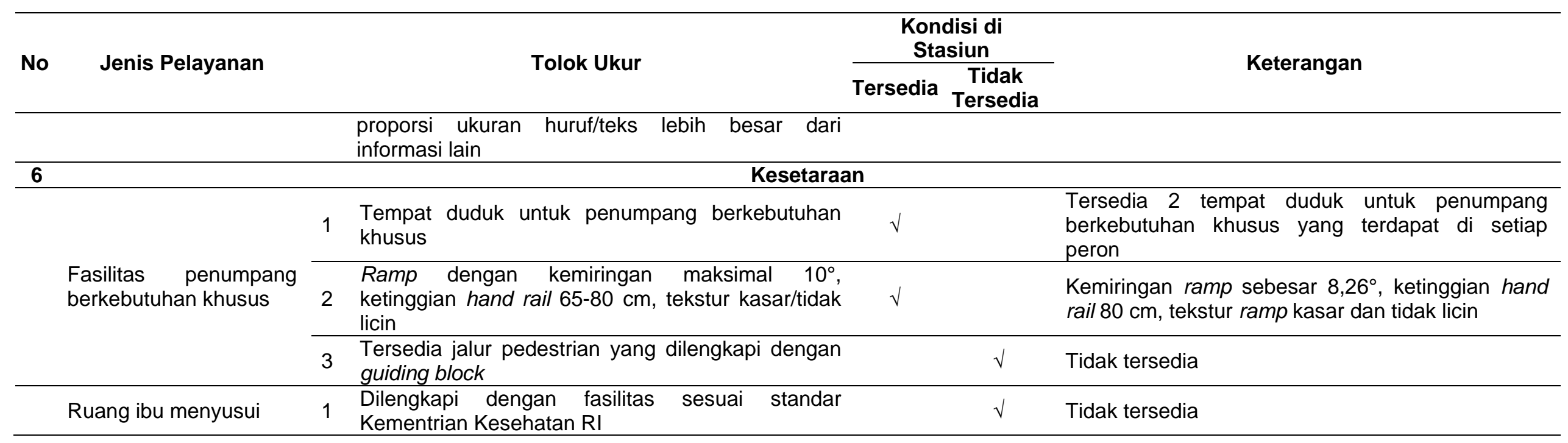


Tabel 5. Pengujian Validitas Tingkat Kinerja dan Tingkat Kepentingan

\begin{tabular}{|c|c|c|c|c|}
\hline \multirow[t]{2}{*}{ Atribut } & \multicolumn{2}{|c|}{$\begin{array}{l}\text { Tingkat } \\
\text { Kinerja }\end{array}$} & \multicolumn{2}{|c|}{$\begin{array}{l}\text { Tingkat } \\
\text { Kepentingan }\end{array}$} \\
\hline & $\mathbf{r}_{\text {hitung }}$ & $r_{\text {tabel }}$ & $\mathbf{r}_{\text {hitung }}$ & $\mathbf{r}_{\text {tabel }}$ \\
\hline 1 & 0,656 & 0,195 & 0,729 & 0,195 \\
\hline 2 & 0,699 & 0,195 & 0,716 & 0,195 \\
\hline 3 & 0,559 & 0,195 & 0,669 & 0,195 \\
\hline 4 & 0,655 & 0,195 & 0,698 & 0,195 \\
\hline 5 & 0,653 & 0,195 & 0,789 & 0,195 \\
\hline 6 & 0,561 & 0,195 & 0,827 & 0,195 \\
\hline 7 & 0,497 & 0,195 & 0,722 & 0,195 \\
\hline 8 & 0,610 & 0,195 & 0,718 & 0,195 \\
\hline 9 & 0,537 & 0,195 & 0,670 & 0,195 \\
\hline 10 & 0,568 & 0,195 & 0,654 & 0,195 \\
\hline 11 & 0,545 & 0,195 & 0,733 & 0,195 \\
\hline 12 & 0,652 & 0,195 & 0,808 & 0,195 \\
\hline 13 & 0,725 & 0,195 & 0,676 & 0,195 \\
\hline 14 & 0,660 & 0,195 & 0,721 & 0,195 \\
\hline 15 & 0,744 & 0,195 & 0,761 & 0,195 \\
\hline 16 & 0,693 & 0,195 & 0,721 & 0,195 \\
\hline 17 & 0,758 & 0,195 & 0,794 & 0,195 \\
\hline 18 & 0,613 & 0,195 & 0,657 & 0,195 \\
\hline 19 & 0,772 & 0,195 & 0,736 & 0,195 \\
\hline 20 & 0,571 & 0,195 & 0,626 & 0,195 \\
\hline 21 & 0,654 & 0,195 & 0,770 & 0,195 \\
\hline 22 & 0,752 & 0,195 & 0,744 & 0,195 \\
\hline 23 & 0,697 & 0,195 & 0,751 & 0,195 \\
\hline 24 & 0,763 & 0,195 & 0,834 & 0,195 \\
\hline 25 & 0,629 & 0,195 & 0,609 & 0,195 \\
\hline
\end{tabular}

Tabel 6. Pengujian Reliabilitas Tingkat Kinerja dan Tingkat Kepentingan

\begin{tabular}{ccc}
\hline $\begin{array}{c}\text { Total } \\
\text { Atribut }\end{array}$ & \begin{tabular}{c} 
Tingkat Kinerja \\
\cline { 2 - 3 }
\end{tabular} & $\begin{array}{c}\text { Tingkat } \\
\text { Kepentingan }\end{array}$ \\
\hline 25 & \multicolumn{2}{c}{ Cronbach's Alpha } \\
\hline
\end{tabular}

Tabel 7. Karakteristik Responden

\begin{tabular}{|c|c|c|}
\hline \multicolumn{2}{|c|}{ Karakteristik Responden } & $\%$ \\
\hline \multirow{2}{*}{ Jenis kelamin } & Pria & $40 \%$ \\
\hline & Wanita & $60 \%$ \\
\hline \multirow{5}{*}{ Usia } & $<20$ tahun & $6 \%$ \\
\hline & 20-30 tahun & $80 \%$ \\
\hline & 31-40 tahun & $7 \%$ \\
\hline & 41-50 tahun & $4 \%$ \\
\hline & $>50$ tahun & $3 \%$ \\
\hline \multirow{3}{*}{$\begin{array}{c}\text { Tingkat } \\
\text { pendidikan }\end{array}$} & SMA & $22 \%$ \\
\hline & D3/S1 & $74 \%$ \\
\hline & Pasca sarjana/S2,S3 & $4 \%$ \\
\hline \multirow{5}{*}{ Pekerjaan } & Pelajar/mahasiswa & $54 \%$ \\
\hline & PNS/TNI & $7 \%$ \\
\hline & Pegawai swasta & $29 \%$ \\
\hline & Wirausaha & $3 \%$ \\
\hline & Tidak bekerja/lainnya & $7 \%$ \\
\hline \multirow{5}{*}{$\begin{array}{c}\text { Tujuan } \\
\text { Perjalanan }\end{array}$} & Sekolah/kuliah & $31 \%$ \\
\hline & Bekerja/bisnis & $31 \%$ \\
\hline & Non bisnis/rekreasi & $7 \%$ \\
\hline & Keperluan pribadi & $26 \%$ \\
\hline & Lainnya & $5 \%$ \\
\hline \multirow{5}{*}{$\begin{array}{c}\text { Frekuensi } \\
\text { penggunaan } \\
\text { KRL } \\
\text { Commuter } \\
\text { Line di Stasiun } \\
\text { Grogol }\end{array}$} & 1 kali dalam seminggu & $6 \%$ \\
\hline & $\begin{array}{ll}2-3 \quad \text { kali dalam } \\
\text { seminggu }\end{array}$ & $14 \%$ \\
\hline & $\begin{array}{l}4-5 \quad \text { kali } \\
\text { seminggu }\end{array}$ & $18 \%$ \\
\hline & Setiap hari & $15 \%$ \\
\hline & Tidak tentu & $47 \%$ \\
\hline
\end{tabular}

\section{Metode IPA}

Metode IPA diawali dengan analisis tingkat kesesuaian, kemudian dilanjutkan dengan perhitungan skor rata-rata untuk tingkat kinerja dan tingkat kepentingan $(\overline{\mathrm{X}}$ dan $\overline{\mathrm{Y}})$ serta batas kuadran $(\overline{\bar{X}}$ dan $\overline{\bar{Y}})$, seperti yang terdapat pada Tabel 8.

Tabel 8. Perhitungan Skor Tingkat Kinerja dan Tingkat Kepentingan Atribut Pelayanan di Stasiun Grogol

\begin{tabular}{|c|c|c|c|c|c|c|}
\hline No & Atribut Pelayanan & $\mathbf{X}_{\mathbf{i}}$ & $\mathbf{Y}_{\mathbf{i}}$ & $\begin{array}{l}\mathrm{TK}_{\mathrm{i}} \\
(\%)\end{array}$ & $\overline{\mathbf{X}}$ & $\overline{\mathbf{Y}}$ \\
\hline \multicolumn{7}{|c|}{ Keselamatan } \\
\hline 1 & Ketersediaan dan kondisi fasilitas keselamatan & 380 & 460 & 82,61 & 3,80 & 4,60 \\
\hline 2 & Ketersediaan dan kondisi fasilitas kesehatan & 335 & 452 & 74,12 & 3,35 & 4,52 \\
\hline 3 & $\begin{array}{l}\text { Kondisi peron dalam memberikan aksesibilitas } \\
\text { naik/turun penumpang }\end{array}$ & 378 & 451 & 83,81 & 3,78 & 4,51 \\
\hline 4 & $\begin{array}{l}\text { Ketersediaan dan kondisi area titik kumpul (assembly } \\
\text { point) }\end{array}$ & 348 & 444 & 78,38 & 3,48 & 4,44 \\
\hline \multicolumn{7}{|c|}{ Keamanan } \\
\hline 5 & Ketersediaan dan kondisi fasilitas keamanan (CCTV) & 351 & 459 & 76,47 & 3,51 & 4,59 \\
\hline 6 & $\begin{array}{l}\text { Kemampuan petugas keamanan dalam menjaga } \\
\text { keamanan, ketertiban, dan kelancaran sirkulasi } \\
\text { penumpang di stasiun }\end{array}$ & 392 & 455 & 86,15 & 3,92 & 4,55 \\
\hline 7 & Kondisi lampu penerangan di stasiun & 381 & 449 & 84,86 & 3,81 & 4,49 \\
\hline \multicolumn{7}{|c|}{ Kehandalan/Keteraturan } \\
\hline 8 & $\begin{array}{l}\text { Kecepatan petugas loket dalam melayani pembelian } \\
\text { tiket elektronik }\end{array}$ & 390 & 449 & 86,86 & 3,90 & 4,49 \\
\hline 9 & $\begin{array}{l}\text { Ketersediaan dan kondisi vending machine untuk } \\
\text { melakukan pembelian ataupun top up tiket elektronik }\end{array}$ & 377 & 442 & 85,29 & 3,77 & 4,42 \\
\hline
\end{tabular}




\begin{tabular}{|c|c|c|c|c|c|c|}
\hline 10 & $\begin{array}{l}\text { Ketersediaan dan kejelasan informasi mengenai tata } \\
\text { cara pembelian dan top up tiket elektronik }\end{array}$ & 380 & 444 & 85,59 & 3,80 & 4,44 \\
\hline 11 & $\begin{array}{l}\text { Kualitas pengeras suara saat menyampaikan informasi } \\
\text { waktu kedatangan kereta ataupun gangguan perjalanan } \\
\text { yang terjadi }\end{array}$ & 403 & 454 & 88,77 & 4,03 & 4,54 \\
\hline \multicolumn{7}{|c|}{ Kenyamanan } \\
\hline 12 & $\begin{array}{l}\text { Ketersediaan dan kondisi toilet dalam memberikan } \\
\text { kenyamanan bagi para pengguna }\end{array}$ & 332 & 461 & 72,02 & 3,32 & 4,61 \\
\hline 13 & $\begin{array}{l}\text { Kondisi musholla dan tempat wudhu dalam memberikan } \\
\text { kenyamanan bagi para pengguna }\end{array}$ & 344 & 450 & 76,44 & 3,44 & 4,50 \\
\hline 14 & $\begin{array}{l}\text { Ketersediaan dan kondisi fasilitas sirkulasi udara } \\
\text { (AC/kipas angin/ventilasi udara) }\end{array}$ & 338 & 442 & 76,47 & 3,38 & 4,42 \\
\hline 15 & Kebersihan dan kerapihan stasiun & 365 & 462 & & U & $L$ \\
\hline \multicolumn{7}{|c|}{ Kemudahan } \\
\hline 16 & $\begin{array}{l}\text { Ketersediaan dan kondisi informasi pelayanan yang } \\
\text { disampaikan, baik dalam bentuk visual ataupun } \\
\text { audio/suara }\end{array}$ & 385 & 459 & 83,88 & 3,85 & 4,59 \\
\hline 17 & $\begin{array}{l}\text { Kecepatan dan ketepatan informasi yang diberikan jika } \\
\text { terjadi gangguan perjalanan kereta }\end{array}$ & 372 & 455 & 81,76 & 3,72 & 4,55 \\
\hline 18 & $\begin{array}{l}\text { Ketersediaan informasi angkutan lanjutan di Stasiun } \\
\text { Grogol }\end{array}$ & 331 & 449 & 73,72 & 3,31 & 4,49 \\
\hline 19 & $\begin{array}{l}\text { Ketersediaan fasilitas layanan penumpang untuk } \\
\text { memberikan informasi perjalanan ataupun layanan } \\
\text { pengaduan }\end{array}$ & 358 & 454 & 78,85 & 3,58 & 4,54 \\
\hline 20 & Ketersediaan dan kondisi area parkir & 251 & 432 & 58,10 & 2,51 & 4,32 \\
\hline 21 & $\begin{array}{l}\text { Kelancaran sirkulasi kendaraan yang masuk, keluar, } \\
\text { ataupun parkir }\end{array}$ & 264 & 447 & 59,06 & 2,64 & 4,47 \\
\hline 22 & $\begin{array}{l}\text { Kelancaran sirkulasi penumpang saat memasuki stasiun } \\
\text { ataupun keluar stasiun }\end{array}$ & 316 & 455 & 69 & 3,16 & 4,55 \\
\hline 23 & $\begin{array}{l}\text { Ketersediaan ruang yang diberikan untuk memudahkan } \\
\text { para penumpang ataupun calon penumpang stasiun } \\
\text { dalam mengakses (naik, turun, dan menunggu) } \\
\text { angkutan umum }\end{array}$ & 303 & 455 & 66,59 & 3,03 & 4,55 \\
\hline \multicolumn{7}{|c|}{ Kesetaraan } \\
\hline 24 & $\begin{array}{l}\text { Ketersediaan dan kondisi fasilitas untuk penumpang } \\
\text { berkebutuhan khusus }\end{array}$ & 334 & 450 & 74,22 & 3,34 & 4,50 \\
\hline 25 & Ketersediaan dan kondisi ruangan untuk ibu menyusui & 287 & 446 & 64,35 & 2,87 & 4,46 \\
\hline & Rata-Rata & & & 77,07 & 3,4780 & 4,5104 \\
\hline
\end{tabular}

Berdasarkan Tabel 8 diperoleh nilai rata-rata tingkat kesesuaian $\left(\mathrm{TK}_{\mathrm{i}}\right)$ yang masih di bawah $100 \%$, yaitu sebesar $77,07 \%$. Artinya secara keseluruhan kinerja dari atribut tersebut masih belum sesuai dengan yang diharapkan, sehingga belum memenuhi kepuasan pengguna stasiun. Selain itu nilai tingkat kesesuaian untuk masingmasing atribut yang masih berada di bawah ratarata menandakan bahwa atribut tersebut harus ditingkatkan lagi kinerjanya. Sedangkan untuk atribut yang memiliki tingkat kesesuaian di atas rata-rata menandakan atribut tersebut sudah baik.

Selanjutnya dilakukan pemetaan hasil perhitungan ke dalam diagram kartesius seperti pada Gambar 2, sehingga dapat dianalisis berdasarkan posisi dari masing-masing atribut tersebut.

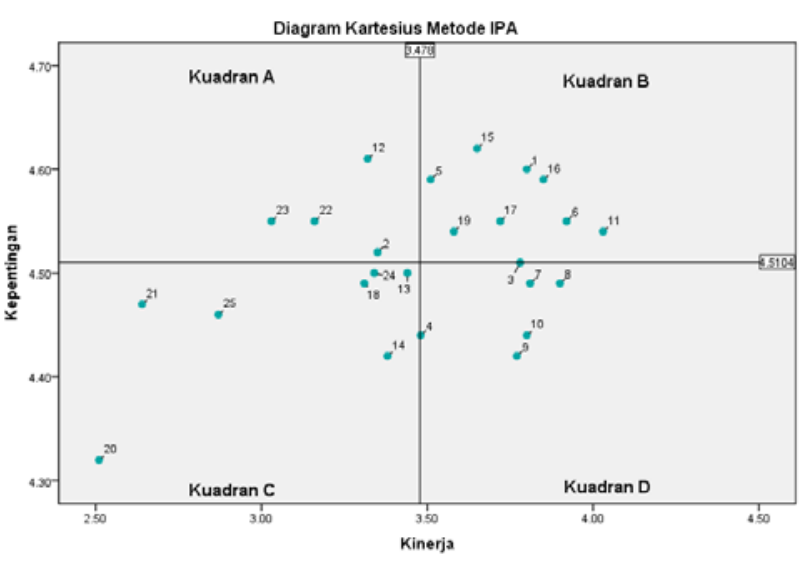

Gambar 2. Hasil Diagram Kartesius di Stasiun Grogol

Atribut pada kuadran A merupakan atribut yang menjadi prioritas utama untuk ditangani, karena atribut ini memiliki tingkat kepentingan yang tinggi, namun kepuasan akan kinerjanya masih rendah. Atribut yang termasuk ke dalam kuadran A yaitu: 
a. Ketersediaan dan kondisi fasilitas kesehatan;

b. Ketersediaan dan kondisi toilet dalam memberikan kenyamanan bagi para pengguna;

c. Kelancaran sirkulasi penumpang saat memasuki stasiun ataupun keluar stasiun;

d. Ketersediaan ruang yang diberikan untuk memudahkan para penumpang ataupun calon penumpang stasiun dalam mengakses angkutan umum.

Atribut pada kuadran B merupakan atribut yang perlu dipertahankan kinerjanya oleh pihak Stasiun Grogol, karena bagi pengguna stasiun atribut ini memiliki kepentingan yang tinggi dan kinerjanya sudah dilaksanakan dengan baik oleh pihak stasiun. Atribut pada kuadran B yaitu:
a. Ketersediaan
dan kondisi fasilitas

keselamatan;

b. Ketersediaan dan kondisi fasilitas keamanan;

c. Kemampuan petugas keamanan dalam menjaga keamanan, ketertiban, dan kelancaran sirkulasi penumpang di stasiun;

d. Kualitas pengeras suara saat menyampaikan informasi waktu kedatangan kereta ataupun gangguan perjalanan yang terjadi;

e. Kebersihan dan kerapihan stasiun;

f. Ketersediaan dan kondisi informasi pelayanan yang disampaikan, baik dalam bentuk visual ataupun audio/suara;

g. Kecepatan dan ketepatan informasi yang diberikan jika terjadi gangguan perjalanan kereta;

h. Ketersediaan fasilitas layanan penumpang untuk memberikan informasi perjalanan ataupun layanan pengaduan.

Atribut pada kuadran $C$ merupakan atribut yang bagi pengguna stasiun memiliki kepentingan yang rendah (kurang penting) dan kepuasan akan kinerjanya juga rendah. Meskipun tergolong kurang penting dan bukan menjadi prioritas utama untuk ditangani, namun tetap harus diperhatikan sesuai kebutuhan dan harapan pengguna stasiun. Atribut pada kuadran $\mathrm{C}$ yaitu:

a. Kondisi musholla dan tempat wudhu dalam memberikan kenyamanan bagi para pengguna;

b. Ketersediaan dan kondisi fasilitas sirkulasi udara;

c. Ketersediaan informasi angkutan lanjutan;

d. Ketersediaan dan kondisi area parkir;

e. Kelancaran sirkulasi kendaraan yang masuk, keluar ataupun parkir;

f. Ketersediaan dan kondisi fasilitas untuk penumpang berkebutuhan khusus;

g. Ketersediaan dan kondisi ruangan ibu menyusui.

Atribut pada kuadran D menandakan bahwa terdapat beberapa atribut yang bagi pengguna stasiun kurang penting, namun kinerjanya dilaksanakan dengan sangat baik oleh pihak stasiun. Oleh karena itu atribut pada kuadran ini bukan menjadi prioritas utama untuk ditangani dan tidak memerlukan perbaikan. Atribut pada kuadran $D$ yaitu:

a. Kondisi peron dalam memberikan aksesibilitas naik/turun penumpang;

b. Ketersediaan dan kondisi area titik kumpul;

c. Kondisi lampu penerangan di stasiun;

d. Kecepatan petugas loket dalam melayani pembelian tiket elektronik;

e. Ketersediaan dan kondisi vending machine untuk melakukan pembelian atau top-up tiket elektronik;

f. Ketersediaan dan kejelasan informasi mengenai tata cara pembelian dan top up tiket elektronik.

\section{Solusi Alternatif}

Berdasarkan hasil yang didapatkan, maka diperlukan solusi alternatif untuk meningkatkan kinerja pada atribut yang menjadi prioritas utama untuk ditangani yaitu atribut yang berada pada kuadran A. Berikut solusi alternatif yang dapat diberikan:

a. Ketersediaan dan kondisi fasilitas kesehatan Pihak stasiun dapat melengkapi tolok ukur yang belum terpenuhi yaitu dengan menyediakan tabung oksigen. Selain itu pihak stasiun juga dapat memperlengkapi obatobatan pada kotak P3K.

b. Ketersediaan dan kondisi toilet dalam memberikan kenyamanan bagi para pengguna

Pihak stasiun dapat melengkapi tolok ukur yang belum terpenuhi yaitu menambahkan fasilitas wastafel dan toilet difabel pada toilet pria. Adanya petugas yang sigap untuk melakukan pembersihan secara rutin juga diperlukan agar toilet slealu bersih dan memberikan kenyamanan bagi para pengguna.

c. Kelancaran sirkulasi penumpang saat memasuki stasiun ataupun keluar stasiun

Pihak stasiun dapat memisahan gate masuk dan gate keluar penumpang pada gate elektronik. Hal ini dikarenakan pada jam sibuk pagi, 4 gate elektronik digunakan untuk penumpang yang turun di Stasiun Grogol untuk menghindari adanya penumpukan penumpang pada area crossing. Oleh karena itu gate elektronik dapat diatur dengan menyediakan 1 gate untuk penumpang yang ingin masuk dan 3 gate lainnya untuk penumpang yang ingin keluar. Begitupun saat jam sibuk sore, 1 gate untuk penumpang yang ingin keluar dan 3 gate untuk penumpang yang ingin masuk.

Pihak Stasiun juga dapat memisahkan pintu masuk dan pintu keluar penumpang untuk mengurangi kepadatan yang terjadi akibat masih tergabungnya akses masuk dan keluar penumpang. Pintu utara dapat diberlakukan 
sebagai pintu masuk dan pintu timur sebagai pintu keluar.

Selain itu perlu adanya pembangunan jembatan penyebrangan sebagai pengganti area crossing yang masih berada di atas jalan rel kereta. Berikut Gambar 3 dan Gambar 4 yang akan menampilkan gambaran solusi untuk mengatasi sirkulasi penumpang di Stasiun Grogol.

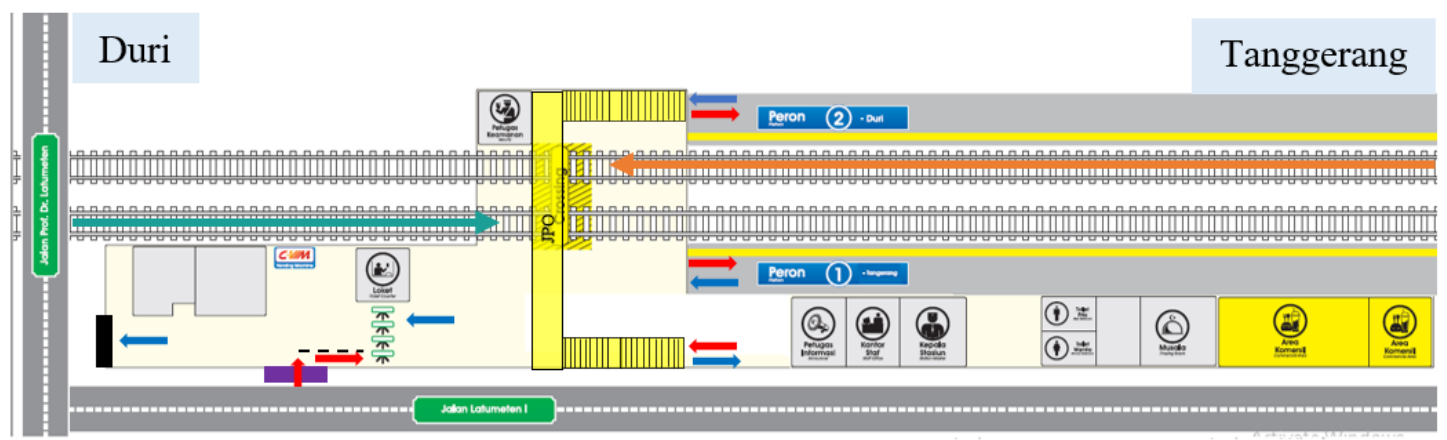

Gambar 3. Penanganan Sirkulasi Penumpang Saat Jam Sibuk Pagi

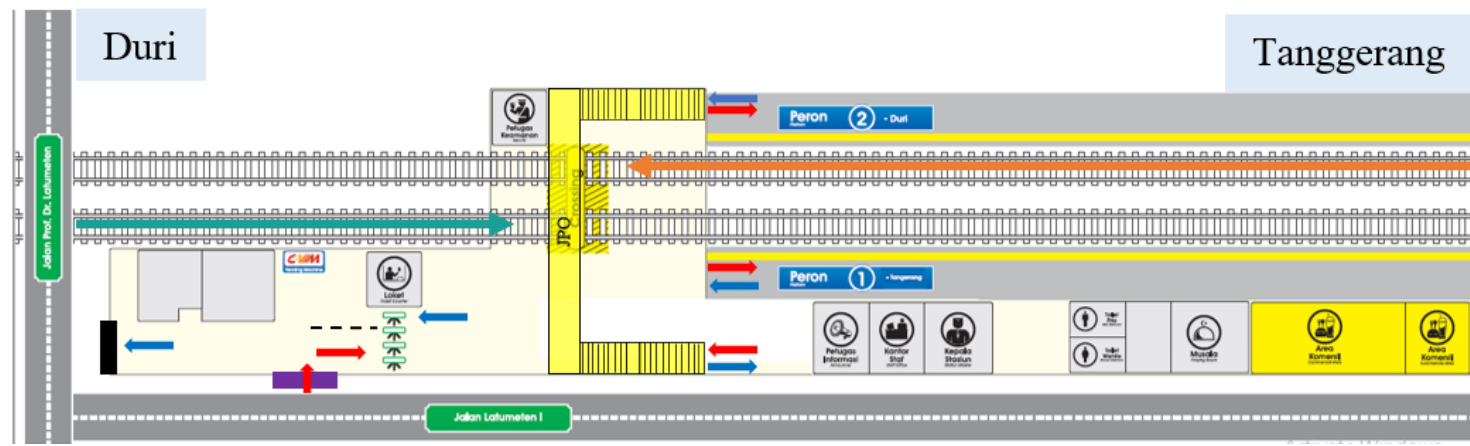

Gambar 4. Penanganan Sirkulasi Penumpang Saat Jam Sibuk Sore

Keterangan:

- Pintu Timur

Pintu Utara

$\leftarrow$ Kereta dari arah Tanggerang - Duri

$\rightarrow$ Kereta dari arah Duri - Tanggerang

- Sirkulasi Kedatangan Penumpang

$\Rightarrow$ Sirkulasi Keberangkatan Penumpang

d. Ketersediaan ruang yang diberikan untuk memudahkan para penumpang ataupun calon penumpang stasiun dalam mengakses angkutan umum

Perlu adanya kajian khusus untuk melakukan penataan kawasan stasiun, seperti menyediakan jalur khusus untuk angkutan umum dan ojek online sehingga memberi kemudahan untuk melakukan integrasi berbagai moda transportasi.

\section{KESIMPULAN}

Berdasarkan hasil evaluasi kinerja pelayanan dan fasilitas di Stasiun Grogol, saat ini stasiun telah memenuhi $78,72 \%$ tolok ukur yang ada di Standar Pelayanan Minimum pada PM 63 Tahun 2019, dengan 10 tolok ukur yang belum terpenuhi.

Kemudian dari hasil analisis tingkat kepuasan penumpang di Stasiun Grogol, diperoleh nilai rata-rata tingkat kesesuaian yang masih di bawah $100 \%$, yaitu $77,07 \%$. Artinya secara keseluruhan kinerja dari atribut tersebut masih belum sesuai dengan yang diharapkan, sehingga belum memenuhi kepuasan pengguna stasiun. Hal ini dapat dilihat dari posisi atribut pada kuadran A yang menjadi prioritas utama untuk ditangani.

Solusi alternatif yang dapat diberikan untuk meningkatkan kinerja atribut pada kuadran A yaitu dengan melengkapi tolok ukur yang masih belum terpenuhi seperti tabung oksigen, fasilitas wastafel dan toilet difabel pada toilet pria, serta perlu menyediakan petugas yang sigap membersihkan toilet secara rutin. Kemudian untuk menangani sirkulasi penumpang, pihak stasiun dapat memisahkan gate masuk dan gate keluar penumpang pada gate elektronik, memisahkan pintu masuk dan pintu keluar penumpang, dan membangun jembatan penyebrangan untuk menggantikan area crossing yang saat ini masih berada di atas jalan rel kereta. Selain itu perlu adanya kajian khusus untuk melakukan penataan kawasan stasiun, seperti menyediakan jalur khusus untuk angkutan umum dan ojek online sebagai upaya menangani permasalahan ketersediaan ruang untuk kemudahan mengakses angkutan umum. 


\section{REFERENSI}

Martinez, C. L. (2003). Evaluation Report: Tools Cluster Networking Meeting. Arizona: Center Point Institute. Inc.

Peraturan Menteri Perhubungan Republik Indonesia Nomor : PM 63. (2019). Standar Pelayanan Minimum Angkutan Orang Dengan Kereta Api.

Pradana, M. F., Budiman, A., \& Arif, I. (2018). Evaluasi Pelayanan Stasiun Tangerang Kota Tangerang. Jurnal Kajian Teknik Sipil, 3(2), 94-104.

PT. KCI. (2020). Data Jumlah Penumpang KRL di Stasiun Grogol.

Riduwan, \& Akdon. (2015). Rumus dan Data dalam Analisis Statistika. Alfabeta.

Saptutyningsih, E., \& Setyaningrum, E. (2020). Penelitian Kuantitatif Metode dan Alat Analisis. Gosyen Publishing.

Sugiyono. (2017). Metode Penelitian Kuantitatif, Kualitatif, dan R\&D. Alfabeta.

Sukardi, \& Chandrawatisma, C. (2006). Analisis Tingkat Kepuasan Pelanggan Terhadap Produk Corned Pronas Produksi PT CIP, Denpasar Bali. Jurnal Teknik Industri Pertanian, 18(2), 106-117.

Supranto, J. (2012). Metode Riset: Aplikasinya Dalam Pemasaran (7th ed.). PT. Rineka Cipta. 